\title{
Task Technical and Quality Assurance Plan for Testing Methods to Reduce 235 Uranium Enrichment in Tank 43H Supernatant Liquid
}

by

D. T. Hobbs

Westinghouse Savannah River Company

Savannah River Site

Aiken, South Carolina 29808

L. N. Oji

M. S. Blume

H. L. Thacker

This paper was prepared in connection with work done under the above contract number with the U.S. Department of Energy. By acceptance of this paper, the publisher and/or recipient acknowledges the U.S. Government's right to retain a nonexclusive, royalty-free license in and to any copyright covering this paper, along with the right to reproduce and to authorize others to reproduce all or part of the copyrighted paper. 


\section{DISCLAIMER}

This report was prepared as an account of work sponsored by an agency of the United States Government. Neither the United States Government nor any agency thereof, nor any of their employees, makes any warranty, express or implied, or assumes any legal liability or responsibility for the accuracy, completeness, or usefulness of any information, apparatus, product or process disclosed, or represents that its use would not infringe privately owned rights. Reference herein to any specific commercial product, process or service by trade name, trademark, manufacturer, or otherwise does not necessarily constitute or imply its endorsement, recommendation, or favoring by the United States Government or any agency thereof. The views and opinions of authors expressed herein do not necessarily state or reflect those of the United States Government or any agency thereof.

This report has been reproduced directly from the best available copy.

Available for sale to the public, in paper, from: U.S. Department of Commerce, National Technical Information Service, 5285 Port Royal Road, Springfield, VA 22161

phone: (800) 553-6847

fax: (703) 605-6900

email: orders@ntis.fedworld.gov

online ordering: http://www.ntis.gov/ordering.htm

Available electronically at http://www.doe.gov/bridge

Available for a processing fee to U.S. Department of Energy and its contractors, in paper, from: U.S. Department of Energy, Office of Scientific and Technical Information, P.O. Box 62, Oak Ridge, TN 37831-0062

phone: (865)576-8401

fax: (865)576-5728

email: reports@adonis.osti.gov 


\section{DISCLAIMER}

Portions of this document may be illegible in electronic image products. Images are produced from the best available original document. 
WSRC-RP-2000-00797

Revision 0

Key Words: HLW,

Evaporator,

Criticality

Task Technical and Quality Assurance Plan for Testing Methods to Reduce ${ }^{235}$ Uranium Enrichment in Tank 43H Supernatant Liquid

D. T. Hobbs

L. N. Oji

M. S. Blume

H. L. Thacker

Publication Date: September 20, 2000

Westinghouse

Savannah River Company

Alken, SC 29808 


\subsection{Introduction ${ }^{1}$}

In July of 1997 , the $2 \mathrm{H}$-Evaporator was shutdown due to the inability to lift material from the vessel. Inspections of the gravity drain line (GDL) showed a scale deposit coating the inside of the line. A sample of the material was obtained and analyses confirmed the deposit was a sodium aluminosilicate scale of the form $\mathrm{Na}_{8} \mathrm{Al}_{6} \mathrm{Si}_{6} \mathrm{O}_{24}\left(\mathrm{NO}_{3}\right)_{2}$. The analyses also showed $\sim 3 \mathrm{wt} \%$ uranium in the form of sodium diuranate $\left(\mathrm{Na}_{2} \mathrm{U}_{2} \mathrm{O}_{7}\right)$ at less than 1 wt\% enriched in ${ }^{235} \mathrm{U}$.

Visual inspection of the evaporator pot showed no evidence of scale deposition or degradation. The GDL was successfully cleaned with an 8000 psi water stream at this time. The GDL was again cleaned with a pressure washer in June 1998. An inspection of the evaporator pot at this time showed minimal deposits on the walls and internal lines. For the rest of 1998 and the first part of 1999, operations continued to experience poor lift performance. Finally in October 1999 , the $2 \mathrm{H}$-Evaporator was shut down due to the inability to lift solution from the evaporator.

Visual internal inspection of the evaporator pot showed a significant buildup of solids on all of the exposed surfaces of the evaporator pot. A sample of the material in the bottom of the evaporator cone was taken at this time. The sample confirmed that the material was the same sodium aluminosilicate scale mixed with sodium diuranate that was found in the gravity drain line, however this material had $~ 7.4 \mathrm{wt} \%$ uranium and was $\sim 3 \mathrm{wt} \%$ ${ }^{235} \mathrm{U}$. Due to the high amount of uranium and the higher enrichment, the $2 \mathrm{H}$ evaporator PISA (Potential Inadequacy in the Safety Analysis) was declared in January 2000. This PISA addresses the unexpected buildup of fissile material in the evaporator pot, resulting in a criticality concern that was not addressed in the current Authorization Basis (AB).

Plans are to chemically clean the evaporator pot by dissolving the solids in a $1.5 \mathrm{M}$ nitric acid solution containing depleted uranium. After cleanout of the evaporator pot, evaporation of liquid wastes will resume using material from Tank $43 \mathrm{H}$. Recent analyses of surface and variable depth samples from Tank $43 \mathrm{H}$ indicate an average total uranium concentration of $15.0 \pm 2.9 \mathrm{mg} / \mathrm{L}$ and average ${ }^{235} \mathrm{U}$ enrichment of $3.12 \pm 0.63 \mathrm{wt} \%$. Thus, as previously observed sodium diuranate solids containing enriched uranium could deposit in the evaporator vessel. Criticality safety during evaporator operation would be enhanced if the enrichment could be reduced to or less than that of natural abundance. HLWE requested that SRTC conduct tests to identify a method to reduce the ${ }^{235} \mathrm{U}$ enrichment in the supernatant liquid presently stored in Tank $43 \mathrm{H}^{2}$

\subsection{Task Description}

Task activities include scoping tests to determine the extent and rate of isotopic dilution of ${ }^{235} \mathrm{U}$ upon the addition of depleted uranium solution to an alkaline solution that simulates supernatant liquid waste currently stored in Tank $43 \mathrm{H}$. The composition of the Tank $43 \mathrm{H}$ simulant will feature most recently reported values obtained from dip samples taken from the tank (see Table I).

Mechanical mixing is limited in Tank $43 \mathrm{H}$ to air/steam sparging. Scoping tests will bound mixing conditions by conducting tests under well-mixed and unmixed conditions. The unmixed tests will be manually shaken just prior to sampling to ensure one obtains and analyzes a representative sample from the test bottle. 
Scoping tests will also include tests that feature a prestrike with freshly precipitated ferric hydroxide or manganese oxide to remove soluble uranium. Prestriking with either of these materials should reduce the liquid phase uranium concentration enabling isotopic dilution of the uranium to proceed at a faster rate. The quantity of sorbent will be selected by the researcher with concurrence with the CST Engineering contact.

\section{Table I. Composition of Tank 43H Supernatant Liquid}

\begin{tabular}{|c|c|c|c|}
\hline Component & Value & $\underline{\text { Unit }}$ & $\underline{\text { Reference }}$ \\
\hline Nitrate & 1.23 & molar & 3 \\
\hline Free Hydroxide & 2.50 & molar & 3 \\
\hline Nitrite & 0.81 & molar & 3 \\
\hline Carbonate & 0.05 & molar & 3 \\
\hline Aluminate & 0.20 & molar & 3 \\
\hline Sulfate & 0.018 & molar & 3 \\
\hline Oxalate & 0.0069 & molar & 3 \\
\hline Phosphate & 0.0064 & molar & 3 \\
\hline Total Uranium & $15.0 \pm 2.9$ & $\mathrm{mg} / \mathrm{L}$ & 4 \\
\hline${ }^{235} \mathrm{U}$ & $3.12 \pm 0.63$ & wt $\%$ & 4 \\
\hline
\end{tabular}

All scoping tests are planned for $25^{\circ} \mathrm{C}$, which is at the lower range of temperatures (24 $38^{\circ} \mathrm{C}$ ) recorded for the supernatant liquid in Tank $43 \mathrm{H}$ over the last 21 months. ${ }^{5}$

Temperature and mixing will be controlled using a shaking waterbath. Unmixed tests may be conducted in a controlled temperature oven if available. An alkaline depleted uranium (DU) solution will be used to isotopically dilute the ${ }^{235} U$ enrichment in the simulant Tank $43 \mathrm{H}$ waste solution. Plans are dissolve the DU in nitric acid to a concentration of between 5 and $30 \mathrm{~g} / \mathrm{L}$. Sodium carbonate will then be added until the solution is alkaline. An alternate test will add the $\mathrm{DU}$ as acidic solution $(\mathrm{pH}=1)$.

Another alternate test will utilize a reverse strike approach where the supernatant liquid is added to the uranium carbonate solution. The density of the DU solution will be adjusted to be similar to that of the Tank $43 \mathrm{H}$ supernate. Having both solutions at or close to the same density will minimize segregation of the two solutions and, thus, promote mixing.

Sufficient DU will be added to reduce the ${ }^{235} U$ enrichment to less than 1 wt $\%$. Uranium isotopics will be measured using inductively coupled plasma - mass spectrometry (ICPMS). ${ }^{6}$ Samples will be taken periodically over a two-week period to measure for ${ }^{235} \mathrm{U}$ enrichment. Sampling frequency and the testing period may adjusted as necessary as scoping test results become available.

Upon completion of testing with simulated waste solutions, WPTS researchers will conduct a confirmatory test with Tank $43 \mathrm{H}$ waste. This test will be conducted in the SRTC Shielded Cells facility. Test conditions for the radioactive waste test will be established based on results from the scoping tests with simulated waste solutions.

Based on the results of the initial scoping tests, WPTS will make recommendations to CST Engineering concerning a process to dilute the ${ }^{235} \mathrm{U}$ enrichment in Tank $43 \mathrm{H}$ 
supernatant liquid. The recommendations will include what, if any, additional tests are needed. The recommendations and a summary of testing results will be issued by WPTS to CST Engineering in a technical report.

\subsection{Risk Review}

Table II highlights the elements identified as programmatic risks. Where available, the table lists mitigating factors or actions. Equipment, analytical services, personnel, facilities, emergent activities, and results contribute to the programmatic risks. The most likely risk in this development involves delays in obtaining the necessary equipment and delays associated with bringing the new experimental equipment on-line.

\section{Table II: Programmatic risk and Mitigation}

\begin{tabular}{|c|c|c|}
\hline Risk Factor & Event & Mitigation \\
\hline \multicolumn{3}{|l|}{ Equipment } \\
\hline $\begin{array}{l}\text { Any equipment needed } \\
\text { to complete this task }\end{array}$ & Breaks & $\begin{array}{l}\text { Replace and shift to alternative } \\
\text { equipment. }\end{array}$ \\
\hline \multicolumn{3}{|l|}{ Personnel } \\
\hline D. T. Hobbs & Unavailable & Shift in technical personnel. \\
\hline L. N. Oji & Unavailable & Shift in technical personnel. \\
\hline M. S. Blume & Unavailable & Shift in technical personnel \\
\hline H. L. Thacker & Unavailable & Shift in technical personnel \\
\hline \multicolumn{3}{|l|}{ Analytical } \\
\hline ICP-MS & Unavailable & Delays program. \\
\hline \multicolumn{3}{|l|}{ 4.0 Schedule } \\
\hline October 6,2000 & \multicolumn{2}{|c|}{ Complete scoping tests } \\
\hline October 13,2000 & \multirow{2}{*}{\multicolumn{2}{|c|}{$\begin{array}{l}\text { Make recommendations ba } \\
\text { Complete draft report }\end{array}$}} \\
\hline October 27,2000 & & \\
\hline November 17,2000 & \multicolumn{2}{|c|}{$\begin{array}{l}\text { Complete confirmatory scoping test with archived } \\
\text { radioactive waste }\end{array}$} \\
\hline
\end{tabular}

\subsection{Safety}

The task leader reviewed the safety aspects of the experiments described in this task plan to determine their impact on the safety of the facilities. The review included evaluation of the checklist from the Conduct of Research and Development Manual, WSRC-IM-9700024 , Rev 2 . The work introduces no new chemicals. No new experimental hazards (such as new electrical, significant quantities of combustible, explosive, or corrosive materials, pressure or mechanical equipment) arise from the planned experiments. 


\subsection{Test Controls}

Samples submitted to the Analytical Development Section for determination of uranium concentration and enrichment will feature blind standards and blanks. The temperature will be controlled and recorded during each test using calibrated testing equipment. The remainder of this section of the document details the controls necessary to ensure the quality of the results obtained in the above detailed tasks performed by WPTS.

\subsection{Task Quality Assurance (QA) Plan Checklist}

See Attachment 1.

\subsection{Additional Comments}

Additional tests not explicitly detailed in this Task and QA plan may be conducted under this task plan without revision provided that in the opinion of the researchers, that the additional tests do not change the hazard assessment for this activity or require new or additional quality assurance controls.

Manual L1 Procedure 3.07 will govern obtaining chemical analyses by the ADS. The ADS uses Manual 1Q Procedure 2-7 for M\&TE. The QA level performed will vary by analysis. 
WSRC-RP-2000-00797

6

September 20, 2000

6.0 Approvals

DITCh

D.T. Hobbs, Author

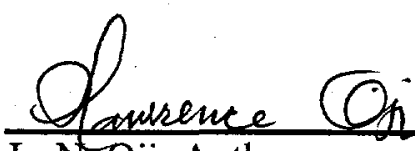

L. N.Oji, Author
$9 / 22 / 00$

Date
M.8. Plume

M. S. Blame, Author

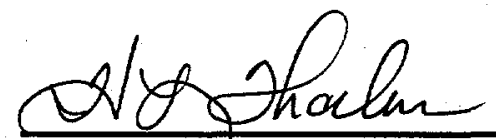

H. L. Whacker, Author
$9 / 22 / 00$

Date

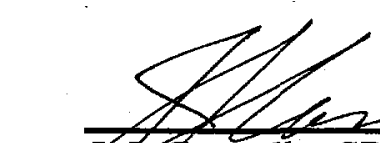

$9 / 22 / 00$

Date

$9 / 22 / 00$

Date

22 SEP DO

Date

W.B. San Feet

$9-25=00$

W. B. Van Pelt, Manager, SRTC WVTS

Date

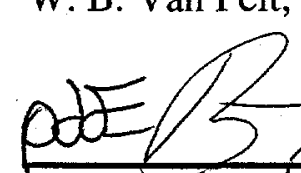

$9-25-a$

Date

B.L. Lewis, Manager, CST Engineering

Date 


\subsection{REFERENCES}

${ }^{1}$ C. S. Boley, M. C. Thompson, W. R. Wilmarth, "Technical Basis for the 242-16H Evaporator Cleaning Flowsheet (U),"'SRS Report WSRC-TR-2000-00211, Rev. 0, July 12, 2000.

2 B. Lewis, "Development of Process to Reduce the Uranium Enrichment in Tank 43," Technical Task Request HLE-TTR-2000-063, Rev. 0, August 17, 2000.

3 Sample Taken from Tank 43H on 7/30/00 and Reported in High-Level Waste Tank Corrosion Chemistry Database maintained CST Engineering and recorded in MS Excel file 'Ntank43.xls'.

4 W. R.Wilmarth and R. A. Peterson, "Analyses of Surface and Variable Depth Samples from Tank 43H," WSRC-TR-2000-00208, Rev. 0, September 2000.

5 Tank farm morning reports [get reference].

6 "Inductively Coupled Plasma - Mass Spectrometry Elemental and Isotopic Analysis for Aqueous Liquid Samples," Manual 16.1, Analytical Development Section Analytical.Operating Procedure ADS-1543, Rev. 1, April 1, 1998. 


\section{WPT TASK QUALITY ASSURANCE PLAN CHECKLIST}

Task Technical Plan No: WSRC-RP-2000-00797 Task Title: Reduction of Tank 43H Uranium Enrichment Listed below are the sections of WSRC 1Q. Check WSRC 19 sections applicable to the task. Also check procedures WPT implements to control the task. This checklist identifies only procedures used to control task activities performed by WPT.

(Form Revised 2/2000)

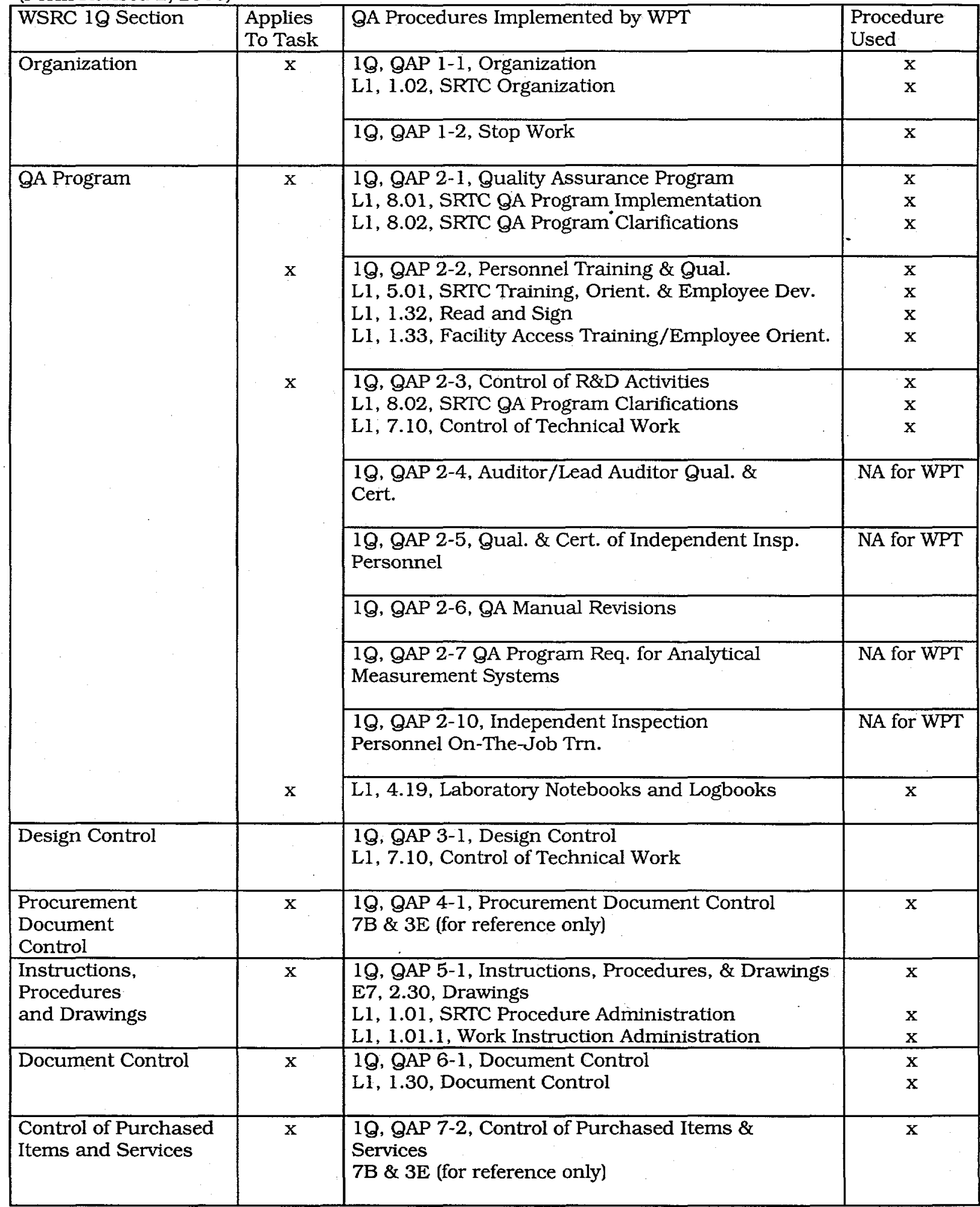




\begin{tabular}{|c|c|c|c|}
\hline & & $\begin{array}{l}\text { 19, QAP 7-3, Com. Grade Item Dedication \& } \\
\text { Material Upgrade } \\
\text { E7, 3.46, Replacement Item Evaluation/Com- } \\
\text { mercial Grade Item Dedication }\end{array}$ & \\
\hline $\begin{array}{l}\text { Identification and } \\
\text { Control of Items }\end{array}$ & $\mathrm{x}$ & $\begin{array}{l}\text { 1Q, QAP 8-1, ID and Control of Items } \\
\text { L1, 8.02, SRTC QA Program Clarifications }\end{array}$ & $\begin{array}{l}\mathrm{x} \\
\mathrm{x}\end{array}$ \\
\hline \multirow[t]{4}{*}{ Control of Processes } & & 1Q. QAP 9-1, Control of Processes & NA for WPT \\
\hline & & $\begin{array}{l}\text { 18, QAP 9-2, Control of Nondestructive } \\
\text { Examination }\end{array}$ & NA for WPT \\
\hline & & $\begin{array}{l}\text { 19, QAP 9-3, Control of Welding \& Joining } \\
\text { Processes } \\
\text { Y12 }\end{array}$ & NA for WPT \\
\hline & & $\begin{array}{l}\text { 19, QAP 9-4, Work Control } \\
\text { 1Y, 8.01, Work Control Procedure } \\
\text { L1, 8.02, SRTC QA Program Clarifications }\end{array}$ & \\
\hline Inspection & & $\begin{array}{l}\text { 18, QAP 10-1, Inspection \& Verification } \\
\text { L1, 8.10, Inspection } \\
\text { L1, 8.10.1, Independent Inspection Releases }\end{array}$ & $\begin{array}{l}\text { NA for WPT } \\
\text { NA for WPT }\end{array}$ \\
\hline Test Control & & $\begin{array}{l}\text { 19, QAP 11-1, Test Control (applies to WPT only for } \\
\text { acceptance testing ) }\end{array}$ & \\
\hline \multirow[t]{3}{*}{$\begin{array}{l}\text { Control of Measuring } \\
\& \text { Test Equipment }\end{array}$} & \multirow[t]{3}{*}{$\mathrm{x}$} & $\begin{array}{l}\text { 1Q, BAP 12-1, Control of Measuring \&Test } \\
\text { Equipment }\end{array}$ & $\mathrm{x}$ \\
\hline & & $\begin{array}{l}\text { 19, QAP 12-2, Control of Installed Process } \\
\text { Instrumentation }\end{array}$ & \\
\hline & & $\begin{array}{l}\text { 19, QAP 12-3, Control \& Calibration of Radiation } \\
\text { Monitoring Equipment }\end{array}$ & \\
\hline $\begin{array}{l}\text { Packaging, Handling, } \\
\text { Shipping \& Storage }\end{array}$ & $\mathbf{x}$ & $\begin{array}{l}\text { 19, QAP 13-1, Pkg., Handling, Ship. \& Storage } \\
\text { L1, 8.02, SRTC GA Program Clarifications }\end{array}$ & $x$ \\
\hline $\begin{array}{l}\text { Inspection, Test, and } \\
\text { Operating Status }\end{array}$ & & $\begin{array}{l}\text { 19, QAP 14-1, Inspection, Test, \& Operating Status } \\
\text { L1, 8.02, SRTC QA Program Clarifications }\end{array}$ & \\
\hline \multirow{2}{*}{$\begin{array}{l}\text { Control of } \\
\text { Nonconforming } \\
\text { Items \& Action }\end{array}$} & \multirow[t]{2}{*}{$\mathrm{x}$} & $\begin{array}{l}\text { 1Q, QAP 15-1, Control of Nonconforming Items } \\
\text { L1, 8.02, SRTC QA Program Clarifications }\end{array}$ & $\mathrm{x}$ \\
\hline & & $\begin{array}{l}\text { 1Q, QAP 15-2, Control of Nonconforming Activities } \\
\text { L1, 8.02, SRTC QA Program Clarifications }\end{array}$ & \\
\hline \multirow{2}{*}{$\begin{array}{l}\text { Corrective Action } \\
\text { System }\end{array}$} & \multirow{2}{*}{$\mathrm{x}$} & 18, QAP 16-1, Corrective Action System & $\bar{x}$ \\
\hline & & 1Q, QAP 16-2, Guality Alert & $\bar{x}$ \\
\hline $\begin{array}{l}\text { Quality Assurance } \\
\text { Records }\end{array}$ & $\mathrm{x}$ & $\begin{array}{l}\text { 1Q, QAP 17-1, Quality Assurance Records Manage- } \\
\text { ment } \\
\text { L1, 8.02, SRTC QA Program Clarifications }\end{array}$ & $\begin{array}{l}\mathrm{x} \\
\mathrm{x}\end{array}$ \\
\hline
\end{tabular}




\begin{tabular}{|c|c|c|c|}
\hline \multirow[t]{4}{*}{ Audits } & \multirow[t]{4}{*}{$\mathrm{x}$} & $\begin{array}{l}\text { 18, QAP 18-2, QA Surveillance } \\
\text { L1, 8.18.1, Surveillance }\end{array}$ & $\begin{array}{l}\mathbf{x} \\
\mathbf{x}\end{array}$ \\
\hline & & $\begin{array}{l}\text { 18, QAP 18-3, QA External Audits } \\
\text { L1, 8.18, SRTC QA Audit Program }\end{array}$ & \\
\hline & & $\begin{array}{l}\text { 19, GAP 18-4, Management Assessments } \\
12 \mathrm{Q} \text {. Assessment Manual }\end{array}$ & \\
\hline & & 19. QAP 18-6, Quality Assurance Internal Audits & \\
\hline Buality Improvement & $\mathrm{x}$ & $\begin{array}{l}\text { 19. QAP 19-2, Quality Improvement } \\
\text { L1, 8.02, SRTC QA Program Clarifications }\end{array}$ & $\begin{array}{l}\mathrm{x} \\
\mathrm{x}\end{array}$ \\
\hline $\begin{array}{l}\text { Software Quality } \\
\text { Assurance }\end{array}$ & & $\begin{array}{l}\text { 18. QAP 20-1, Software QA } \\
\text { L1, 8.20, Software Management \& Quality } \\
\text { Assurance }\end{array}$ & . \\
\hline $\begin{array}{l}\text { Environmental } \\
\text { Quality } \\
\text { Assurance }\end{array}$ & & $\begin{array}{l}\text { 18, QAP 21-1, Quality Assurance Requirements for } \\
\text { the Collection and Evaluation of Environmental } \\
\text { Data }\end{array}$ & NA for WPT \\
\hline
\end{tabular}


Distribution: S. M. Aleman, 703-H

C. I. Aponte, $703-\mathrm{H}$

C. S. Boley, 703-H

T. E. Britt, 703-H

J. T. Carter, 704-3N

P. D. d'Entremont, 703-H

V. G. Dickert, 703-H

L. O. Dworjanyn, 735-11A

S. D. Fink, 773-A

J. M. Gillam, 704-27S

D. T. Hobbs, 773-A

R. T. Jones, 704-3N

M. A. Kyle, 723-A

B. L. Lewis, 703-H

T. J. Lex, 703-H

S. L. Marra, 704-T

D. J. Martin, 703-H

T. M. Monahon, 703-H

J. P. Morin, 703-H

T. A. Nance, 723-A

C. A. Nash, 773-42A

C. G. Nickell, 703-H

L. N. Oji, 773-43A

J. F. Ortaldo, 704-F

L. M. Papouchado, 773-A

T. B. Peters, 773-24A

R. A. Peterson, 773-A

R. A. Pierce, 773-A

J. A. Pike, $704-196 \mathrm{~N}$

M. R. Poirier, 773-42A

R. H. Ross, 703-H

R. F. Swingle, 773-A

W. L. Tamosaitis, 773-A

M. C. Thompson, 773-A

W. B. Van Pelt, 773-42A

W. R. Wilmarth, 773-42A

G. T. Wright, 773-A

STI, 703-43A (4 copies)

LWPT Files c/o C. C. Canada, 773-A 